\title{
PENGARUH REPUTASI KAP TERHADAP REAKSI INVESTOR MELALUI PERGANTIAN KAP SECARA VOLUNTARY PADA PERUSAHAAN INDEKS LQ 45 YANG TERDAFTAR DI BURSA EFEK INDONESIA
}

\author{
Lydia Victoria $^{1}$, Bahtiar Effendi ${ }^{2}$ \\ Universitas Matana ${ }^{1,2}$ \\ E-mail: bahtiar.effendi@matanauniversity.ac.id
}

\begin{abstract}
The purpose of this study is to investigation over the influence of Accounting Firms Reputation to investor reaction by Switching in accounting firms as a intervening variable (mediation). In this study investor reaction wil be obtained from abnormal return as a scale ratio. Total of all the samples that use in this study is 125 company from LQ45 in Indonesian Stock Exchange from 2014-2018. The samples are acquired using purposive sampling method, the data is acquired from annual reports that publish by the company to investor. This study is use path analysis because there is an intervening variable in this study. The result of this research is obtained that there is an influence from accounting firms reputation to switching in accounting firms, then switch in accounting firms as an intervening variable is able to give an indirect effect from accounting firms reputation to investor reaction, there is no direct effect between each variable of accounting firms reputation and switch in accounting firms to investor reaction (abnormal return).
\end{abstract}

Keywords: accounting firms reputation, switch in accounting firms, and abnormal return

\section{Pendahuluan}

Perusahaan privat yang memilih untuk menjadi perusahaan go public, dengan mendaftarkan perusahaannya di Bursa Efek Indonesia (BEI) akan diminta untuk lebih bersifat terbuka kepada masyarakat luas (Sudarno dan Handoko, 2015). Setelah menjadi perusahaan go public, maka perusahaan akan membuka kesempatan kepada masyarakat luas untuk dapat melakukan investasi, dengan membeli saham yang dijual perusahaan melalui BEI. Adanya perubahan kebijakan yang dilakukan perusahaan pada suatu informasi akuntansi dapat menimbulkan reaksi investor.

Oleh karena itu, kebijakan perusahaan dalam menggunakan jasa KAP yang memiliki reputasi baik maupun dalam melakukan pergantian KAP dapat mempengaruhi reaksi investor. Untuk melihat akibat dari reaksi investor karena adanya penggunaan jasa KAP dengan reputasi baik dan terjadinya pergantian KAP, maka digunakan perubahan harga saham yang ditandai dengan adanya abnormal return saham bersifat positif atau bersifat negatif (Susanto dan Handoko, 2015). Investor dapat memperkirakan (mengestimasi) nilai yang diharapkan dari return sekuritas melalui informasi akuntansi yang disajikan perusahaan emiten.

Dalam usaha meyakinkan investor sebagai pemakai laporan keuangan sebagai bentuk informasi akuntansi, maka laporan keuangan yang disusun oleh manajemen harus bebas dari salah saji material, bebas dari kecurangan dan manipulasi (harus akurat sesuai dengan 
keadaan sebenarnya). Untuk mewujudkan upaya meyakinkan investor, maka perusahaan emiten akan membutuhkan jasa audit atas laporan keuangan yang dilakukan oleh pihak eksternal perusahaan, yaitu KAP yang bersifat independen serta kompeten. Adanya reputasi Kantor Akuntan Publik (KAP) baik Big Four maupun Non Big Four akan mendapat penilaian tersendiri dari investor yang akan melakukan investasi.(Fernandes dan Susanto, 2012).

Terdapat salah satu kasus yang melibatkan jasa KAP Big Four dan menimbulkan reaksi investor. Mengutip dari "Warta Ekonomi", yang berjudul "Ketika Skandal Fraud Akuntansi Menerpa British Telecom dan PwC", terdapat kasus fraud salah satu perusahaan besar multinasional, yang melibatkan salah satu KAP Big Four (PricewaterhouseCoopers/ $P w C)$. British Telecom, mengalami kasus fraud pada salah satu lini usahanya yang berada di Italia dan mulai diketahui sejak awal triwulan kedua 2017. PwC (PricewaterhouseCoopers) sebagai pihak auditor telah dianggap gagal dalam mendeteksi adanya fraud. PwC juga dianggap telah melanggar prinsip integritas dan prinsip perilaku professional dalam menjalankan tugas, serta fungsinya sebagai auditor. Akhirnya terjadi pergantian KAP dari PwC ke KPMG (keduanya termasuk ke dalam KAP Big Four). Lalu, investor juga bereaksi dengan adanya perubahan harga saham yang turun drastis (anjlok) hingga seperlimanya, dikarenakan oleh adanya pengumuman koreksi pendapatan British Telecom sebesar GBP530 juta di bulan Januari 2017. Investor yang sudah membeli saham British Telecom juga merasa dirugikan karena adanya penurunan harga saham tersebut.

Pada kasus diatas diketahui bahwa KAP digunakan untuk memberikan jasa audit atas laporan keuangan yang sudah dibuat oleh pihak manajemen. Di Indonesia sendiri terdapat aturan yang mengatur tentang penggunaan jasa akuntan publik maupun Kantor Akuntan Publik (KAP). Peraturan tersebut tertuang dalam Peraturan Menteri Keuangan (PMK) No. 17/PMK.01/2008 tentang Jasa Akuntan Publik. Dalam pasal 3 ayat (1) dijelaskan bahwa sebuah KAP hanya boleh mengaudit suatu perusahaan paling lama 6 tahun buku berturutturut. Sedangkan untuk Akuntan Publik (AP) dalam KAP tersebut diperbolehkan mengaudit paling lama 3 tahun buku berturut-turut. Pada kedua aturan KMK tersebut disebutkan bahwa baik auditor perorangan maupun pergantian pihak KAP memiliki batas jangka waktu tertentu dalam memberikan jasa auditnya. Reputasi KAP menjadi salah satu faktor yang dapat menyebabkan terjadinya pergantian KAP. Pergantian KAP dikategorikan ke dalam dua jenis, yaitu pergantian KAP secara mandatory (ditetapkan pemerintah) maupun voluntary (sukarela).

Pada penelitian ini, Penulis akan menggunakan variable independen berupa reputasi KAP, lalu melihat bagaimana pengaruh reputasi KAP secara langsung terhadap reaksi investor (sebagai variable dependen). Penelitian mengenai pengaruh reputasi KAP terhadap reaksi investor sudah pernah dilakukan oleh Fernandes dan Susanto (2012), Anna dan Diputra (2014). Berdasarkan penelitian yang dilakukan oleh Fernades dan Santoso (2012) dinyatakan bahwa reputasi KAP memiliki pengaruh signifikan terhadap reaksi investor. Hasil penelitian tersebut didukung dengan penelitian yang dilakukan oleh Anna dan Diputra (2014), yang menunjukkan bahwa perusahaan yang diaudit oleh KAP Big Four dapat menimbulkan reaksi dari investor.

Kemudian Penulis akan melihat bagaimana pengaruh langsung dari variabel pergantian KAP secara voluntary terhadap reaksi investor. Penelitian terdahulu mengenai pengaruh pergantian KAP terhadap reaksi investor sudah pernah dilakukan oleh Fernandes dan Santoso (2012). Anna dan Diputra (2014), dan Herdiana (2017). Reputasi KAP dianggap tidak berpengaruh signifikan berdasarkan penelitian yang dilakukan oleh Fernandes dan Santoso (2012). Hasil penelitian tersebut sama dengan penelitian yang dilakukan oleh Anna dan Diputra (2014), dimana cumulative abnormal return negatif yang menunjukkan investor tidak bereaksi meskipun perusahaan melakukan pergantian KAP secara voluntary. Tetapi, berdasarkan penelitian yang dilakukan oleh Herdiana (2017) dinyatakan bahwa pergantian 
KAP berpengaruh signifikan terhadap reaksi investor. Karena semakin tinggi pergantian KAP akan meningkatkan juga abnormal return dari perusahaan yang bersangkutan.

Pada penelitian ini terdapat variabel intervening, maka Penulis akan melakukan penelitian mengenai pengaruh tidak langsung dari reputasi KAP terhadap reaksi investor, melalui pergantian KAP (variabel intervening). Pertama dilakukan penelitian mengenai pengaruh reputasi KAP terhadap pergantian KAP sudah pernah dilakukan di Indonesia. Kemudian dilakukan penelitian kembali mengenai dampak dari pergantian KAP (yang disebabkan adanya reputasi KAP) terhadap reaksi investor.

Penelitian mengenai pengaruh reputasi KAP terhadap pergantian KAP sudah pernah dilakukan oleh Astrini dan Muid (2013), Susiani, Yuniarti, dan Restian (2017), dan Widnyani dan RM (2017). Kedua penelitian tersebut sama-sama membahas variable independen berupa reputasi KAP dan pengaruhnya terhadap pergantian KAP. Pada penelitian yang dilakukan oleh Astrini dan Muid (2013), serta Widnyani dan RM (2018), dinyatakan bahwa reputasi KAP (baik KAP Big Four maupun KAP Non Big Four) tidak berpengaruh signifikan terhadap pergantian KAP. Hasil penelitian tersebut berbeda dengan penelitian yang dilakukan oleh Susiani, Yuniarti, dan Restian (2017), dinyatakan bahwa reputasi KAP berpengaruh signifikan terhadap auditor switching (khususnya pergantian KAP).

Penelitian ini merupakan replikasi dari penelitian yang sebelumnya pernah dilakukan oleh Anna dan Diputra (2014). Pada penelitian ini digunakan variabel independen berupa reputasi KAP dan variabel dependen berupa reaksi investor, kedua variabel tersebut sama dengan variabel yang digunakan oleh Anna dan Diputra (2014).

Perbedaan penelitian ini dengan sebelumnya adalah menambahkan variabel intervening berupa pergantian KAP. Sehingga rumusan masalah dari penelitian ini adalah sebagai berikut: (1). Apakah reputasi KAP berpengaruh langsung terhadap reaksi investor pada perusahaan LQ 45 yang terdaftar di BEI 2014-2018?; (2). Apakah reputasi Kantor Akuntan Publik (KAP) berpengaruh terhadap pergantian KAP secara voluntary pada perusahaan LQ 45 yang terdaftar di BEI 2014-2018?; (3). Apakah pergantian KAP secara voluntary berpengaruh langsung terhadap reaksi investor pada perusahaan LQ 45 yang terdaftar di BEI 2014-2018?; (4).Apakah terdapat pengaruh tidak langsung antara reputasi KAP terhadap reaksi investor melalui pergantian KAP secara voluntary sebagai variable intervening pada perusahaan LQ 45 yang terdaftar di BEI 2014-2018?

\section{Tinjauan Literatur dan Pengembangan Hipotesis}

Teori Sinyal. Pengambilan keputusan yang dilakukan investor di pasar modal dalam berinvestasi, akan dipengaruhi oleh penyajian informasi yang dipublikasikan emiten kepada publik. Menurut Hartono (2008:529) dalam mengambil keputusan investasi, maka investor sangat memerlukan informasi yang dipublikasikan secara lengkap, tepat waktu, akurat dan relevan. Adanya informasi yang dipublikasikan sebagai suatu pengumuman, akan memberikan sinyal bagi investor dalam melakukan investasi (Anna dan Diputra, 2014).

Terdapat beberapa pengumuman yang biasanya digunakan dalam teori ini, diantaranya adalah pengumuman yang berhubungan dengan laba, pengumuman deviden, pengumuman mengenai aktivitas pendanaan dan investasi, pengumuman yang berkaitan dengan kegiatan pemerintah, pengumuman tentang ketenagakerjaan, pengumuman yang berkaitan dengan hukum dan kegiatan produksi, pemasaran serta penjualan, pengumuman dari manajemen dan direksi, hingga pengumuman yang berhubungan dengan sekuritas (Hartono, 2008: 495). Pengumuman berupa sinyal yang diberikan perusahaan dapat tersaji dalam bentuk laporan yang diwajibkan maupun pengumuman yang berkaitan dengan pengambilan keputusan yang dilakukan oleh perusahaan. Suatu pengumuman yang dipublikasikan dikatakan mengandung informasi apabila dapat memicu reaksi pasar, yaitu 
dapat berupa perubahan harga saham atau abnormal return. Apabila pengumuman tersebut memberikan dampak positif berupa kenaikan harga saham, maka pengumuman tersebut merupakan sinyal positif, tetapi jika pengumuman tersebut memberikan dampak negatif, maka pengumuman tersebut merupakan sinyal negatif (Wicaksono, 2012).

Teori Keagenan. Jensen dan Meckling menyebutkan bahwa terdapat perbedaan kepentingan antara pihak principal dengan agent, pada umumnya principal akan memaksimalkan keuntungan untuk dirinya sendiri. Sementara itu, agent sebagai manajer perusahaan memiliki kewajiban untuk menyampaikan informasi tentang kondisi perusahaan yang sebenarnya (tidak dimanipulasi) kepada principal. Masalah keagenan akan muncul akibat adanya perbedaan kepentingan antara agent dan principal. Selanjutnya masalah keagenan ini terbagi kedalam dua kategori, yaitu adverse selection dan moral hazard. Adverse selection terjadi ketika agent (manajer perusahaan) gagal memberikan kemampuannya terhadap kontrak yang sudah terjadi dan merugikan pihak principal. Sedangkan moral hazard menunjukkan bahwa agent tidak melaksanakan tanggung jawabnya, dengan bertindak untuk keuntungannya sendiri tanpa sepengetahuan principal (Trinugroho dan Lau, 2019: 149).

Pada perusahaan publik, adanya perbedaan kepentingan antara pihak agent dan principal menyebabkan dilakukannya proses pengungkapan terhadap laporan keuangan yang sudah dibuat manajemen melalui jasa Kantor Akuntan Publik (KAP). Dimana KAP memberikan jaminan secara independen kepada investor bahwa laporan keuangan yang disajikan perusahaan auditee telah sesuai dengan prinsip akuntansi yang berlaku, dan memberikan opini mengenai kewajaran dari setiap data yang tersaji pada laporan keuangan bersangkutan. Tingkat kepercayaan terhadap hasil audit atas laporan keuangan akan bertambah dan ditunjukkan dengan reaksi investor yang tercermin dari harga saham (Subroto, 2014).

Reputasi KAP. Secara umum, Kantor Akuntan Publik (KAP) adalah badan usaha yang telah mendapatkan izin dari Menteri Keuangan sebagai wadah bagi akuntan publik dalam memberikan jasanya. Setiap KAP memiliki perbedaan kualitas dan reputasi antara satu dengan yang lainnya, sehingga akan menyebabkan perusahaan go public perlu melakukan pemilihan terhadap Kantor Akuntan Publik (KAP) yang dianggap memiliki reputasi baik dan berkualitas untuk melaksanakan pengauditan terhadap laporan keuangan perusahaan auditee, pada waktu Initial Public Offering (IPO) maupun setelah perusahaan auditee sudah terdaftar pada pasar modal (Subroto, 2014).

Di Indonesia terdapat 4 KAP terbesar yang berafiliasi dengan Big Four Accounting Firms. Berikut ini adalah daftar KAP di Indonesia yang berafiliasi dengan Big Four Accounting Firms di antaranya adalah: 1). Deloitte berafiliasi dengan KAP Satrio Bing Eny \& Rekan; 2). PricewaterhouseCoopers berafiliasi dengan KAP Tanudiredja, Wibisana, Rintis \& Rekan; 3). Ernst \& Young berafiliasi dengan KAP Purwantono, Sungkoro \& Surja; dan 4). KPMG berafiliasi dengan KAP Sidharta Widjaja \& Rekan.

Pergantian KAP. Pada penelitian ini akan dibahas mengenai pergantian KAP secara voluntary. Penulis menggunakan variabel pergantian KAP secara voluntary (bukan mandatory), untuk melihat apakah terdapat faktor tertentu yang dialami perusahaan sehingga perusahan mengganti KAPnya secara sukarela (tanpa ada paksaan). Terdapat 2 faktor yang dapat mengakibatkan terjadinya pergantian jasa KAP, yaitu dapat dilakukan dengan memberhentikan penggunaan jasa KAP oleh perusahaan (klien) ataupun KAP sendiri yang melakukan pengunduran diri. Pergantian KAP secara voluntary dapat terjadi karena hasil audit yang dilakukan oleh auditor tidak sesuai dengan kebijakan yang diatur dalam perusahaan. Selain itu reputasi KAP juga menjadi penilaian perusahaan dalam menggunakan 
jasa audit. Untuk mendapat hasil audit yang bermutu, maka perusahaan akan memilih auditor yang sudah memiliki nama baik dibidang jasa audit.

Reaksi Investor. Reaksi investor adalah respon dari investor ketika terjadi peristiwa tertentu pada hasil saham dari sejumlah keuntungan yang diharapkannya atas hasil investasi di masa depan (Herdiana, 2017). Hasil investasi disebut juga sebagai return, yang dapat berupa keuntungan ataupun kerugian tergantung dari nilai investasi pada periode tertentu. Pengukuran reaksi investor dapat dilakukan dengan menghitung Abnormal return (AR). Menurut Jogiyanto (2013), abnormal return merupakan "selisih antara return yang sesungguhnya terjadi dengan return ekspektasi”. Jogiyanto (2013) juga menyatakan bahwa return normal merupakan return ekspektasi atau return yang diharapkan investor. Sedangkan return sesungguhnya adalah return yang terjadi pada waktu ke-t yang merupakan selisih harga sekarang terhadap harga saham sebelumnya. Lalu return ekspekstasi merupakan return yang harus diestimasi.

\section{Kerangka Pemikiran}

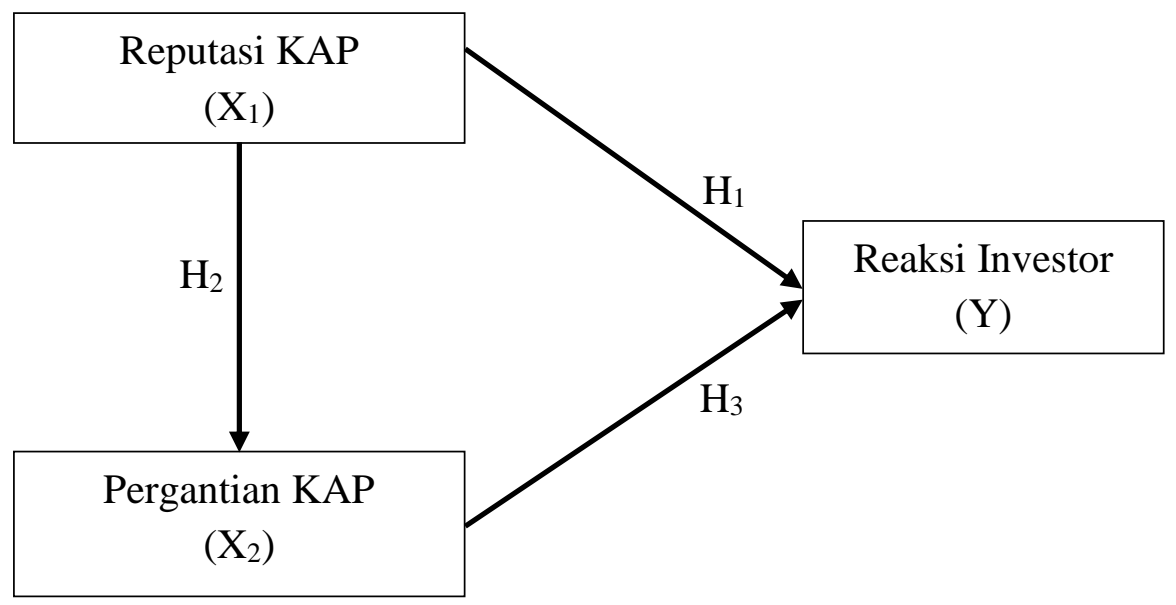

Keterangan:

Gambar 1. Kerangka Pemikiran

$$
\begin{array}{ll}
\longrightarrow & \text { Pengaruh interaksi variabel independen terhadap variabel dependen } \\
& \text { maupun variabel intervening } \\
= & \text { Variabel independen } \\
\mathrm{X}_{1} & \text { Variabel intervening } \\
\mathrm{X}_{2} & =\text { Variabel dependen } \\
\mathrm{Y} &
\end{array}
$$

Kerangka pemikiran dalam penelitian ini terdiri dari beberapa hal berikut ini:

1. Pengaruh reputasi KAP terhadap reaksi investor;

2. Pengaruh reputasi KAP terhadap pergantian KAP secara voluntary;

3. Pengaruh pergantian KAP secara voluntary terhadap reaksi investor;

4. Pengaruh pergantian KAP secara voluntary sebagai variabel intervening (mediasi) antara reputasi KAP terhadap reaksi investor.

Keterkaitan Reputasi KAP Terhadap Reaksi Investor. Penelitian mengenai pengaruh reputasi KAP terhadap reaksi investor pernah dilakukan oleh Susanto dan Fernandes (2012), yang hasilnya dinyatakan reputasi KAP berpengaruh terhadap reaksi investor. Dimana investor akan melakukan investasi, apabila perusahaan go public menggunakan jasa KAP bereputasi baik (KAP Big Four). Selain itu penelitian serupa juga pernah dilakukan oleh 
Anna dan Diputra (2014) yang hasilnya disimpulkan bahwa reputasi Kantor Akuntan Publik (KAP) berpengaruh signifikan terhadap reaksi investor, yang hasilnya mendukung penelitian dari Susanto dan Fernandes (2012). Hal ini ditunjukkan dengan adanya nilai Cumulative abnormal return (CAR) yang positif, sehingga KAP Big Four dianggap dapat menimbulkan adanya reaksi investor.

Kantor Akuntan Publik Big Four maupun Non Big Four memiliki penilaian tersendiri dari investor. Kantor Akuntan Publik Big Four yang memiliki reputasibaik dapat menjadi acuan untuk menyakinkan investor dalam berinvestasi, oleh karena itu dapat pengaruh terhadap reaksi investor. Sehingga $\mathrm{H}_{1}$ dinyatakan sebagai berikut:

$\mathrm{H}_{1}$ : Reputasi KAP (Big Four) berpengaruh terhadap reaksi investor pada perusahaan LQ 45 yang terdaftar di BEI periode 2014- 2018.

Keterkaitan Reputasi KAP Terhadap Pergantian KAP Secara Voluntary. Penelitian mengenai pengaruh reputasi KAP terhadap pergantian KAP sudah pernah dilakukan di Indonesia. Seperti penelitian yang dilakukan oleh Astrini dan Muid (2013), Widnyani dan RM (2018), dan Susiani, Yuniarti, dan Restian (2017). Ketiga jurnal tersebut sama-sama membahas variable independen berupa reputasi KAP dan pengaruhnya terhadap pergantian KAP. Pada penelitian yang dilakukan oleh Astrini dan Muid (2013), yang hasilnya menyatakan bahwa reputasi KAP tidak berpengaruh signifikan terhadap pergantian KAP secara voluntary. Karena perusahaan yang sudah menggunakan jasa KAP Big Four akan mempertahankan penggunaan jasa KAP bersangkutan, untuk dapat meningkatkan kredibilitas perusahaan dimata para pemakai laporan keuangan. Hasil penelitian Widnyani dan RM (2018) juga menyatakan bahwa reputasi KAP (baik KAP Big Four maupun KAP Non Big Four) tidak berpengaruh signifikan terhadap pergantian KAP.

Hasil penelitian tersebut berbeda dengan penelitian yang dilakukan oleh Susiani, Yuniarti, dan Restian (2017), dinyatakan bahwa reputasi KAP berpengaruh signifikan terhadap pergantian KAP. Perusahaan yang sebelumnya menggunakan jasa KAP Non Big Four akan lebih memilih untuk menggunakan jasa KAP Big Four, agar dapat meningkatkan kredibilitasnya di mata para calon investor. Reputasi KAP, baik yang tergabung dalam $K A P$ Big Four maupun KAP Non Big Four akan mempengaruhi terjadinya pergantian KAP. Oleh karena itu, $\mathrm{H}_{2}$ dapat dinyatakan sebagai berikut ini:

$\mathrm{H}_{2}$ : Reputasi KAP (Big Four) berpengaruh terhadap terjadinya pergantian KAP secara voluntary pada perusahaan LQ 45 yang terdaftar di BEI periode 2014- 2018.

Keterkaitan Pergantian KAP Secara Voluntary Terhadap Reaksi Investor. Berdasarkan hasil penelitian yang dilakukan oleh Susanto dan Fernandes (2012), pergantian KAP tidak memiliki pengaruh terhadap reaksi investor. Karena dalam melakukan investasi, investor menganggap bahwa pergantian KAP dianggap sebagai hal yang wajar. Sehingga pergantian KAP tidak berpengaruh terhadap harga saham. Hasil penelitian tersebut sama dengan penelitian yang dilakukan oleh Anna dan Diputra (2014), dimana cumulative abnormal return negatif yang menunjukkan investor tidak bereaksi meskipun perusahaan melakukan pergantian KAP secara voluntary. Tetapi, berdasarkan penelitian yang dilakukan oleh Herdiana (2017) dinyatakan bahwa pergantian KAP berpengaruh signifikan terhadap reaksi investor. Karena semakin tinggi pergantian KAP akan meningkatkan juga abnormal return dari perusahaan yang bersangkutan. Adanya penurunan maupun peningkatan kualitas laporan keuangan yang diakibatkan oleh adanya Pergantian KAP akan berdampak juga terhadap tingkat kepercayaan investor kepada kinerja perusahaan, yang ditunjukkan dalam bentuk laporan keuangan (Ngaijan, 2017). Sehingga $\mathrm{H}_{3}$ dinyatakan sebagai berikut:

$\mathrm{H}_{3}$ : Pergantian KAP secara voluntary berpengaruh terhadap reaksi investor pada perusahaan LQ 45 yang terdaftar di BEI periode 2014-2018. 
Keterkaitan Reputasi KAP Terhadap Reaksi Investor Melalui Pergantian KAP Secara Voluntary. Reputasi KAP menjadi salah satu faktor yang dapat menyebabkan terjadinya pergantian KAP. Seperti penelitian yang telah dilakukan oleh Susiani, Yuniarti, dan Restian (2017), dinyatakan bahwa reputasi KAP berpengaruh signifikan terhadap pergantian KAP. Dimana, perusahaan yang sebelumnya menggunakan jasa KAP Non Big Four akan lebih memilih untuk menggunakan jasa KAP Big Four, agar dapat meningkatkan kredibilitasnya di mata para calon investor. Selanjutnya, Penulis akan melihat bagaimana dampak dari pergantian KAP (yang disebabkan oleh reputasi KAP) terhadap reaksi investor. Menurut Subroto (2014:21-22) dinyatakan bahwa pengauditan yang dilakukan oleh KAP besar (reputasi baik) dapat menjadikan saham perusahaan auditee menjadi lebih mudah untuk diperdagangkan. Pemakaian KAP yang berkualitas tinggi dan mahal akan menjadi signal bahwa perusahaan yang diaudit adalah perusahaan yang baik. Karena pada umumnya KAP besar mempunyai pemahaman tentang ketentuan pasar modal yang baik, sehingga dapat mendorong kinerja kliennya untuk lebih mematuhi aturan dan ketentuan yang diwajibkan. Oleh karena itu, $\mathrm{H}_{4}$ dinyatakan sebagai berikut ini:

$\mathrm{H}_{4}$ : Reaksi investor merupakan variabel intervening (mediasi) antara reputasi KAP (Big Four) melalui reaksi investor pada perusahaan LQ 45 yang terdaftar di BEI periode 20142018.

\section{Metode Penelitian}

Berdasarkan jenis data yang digunakan, penelitian ini merupakan penelitian kuantitatif karena menggunakan data berupa angka-angka. Selanjutnya, berdasarkan karakteristik masalahnya, penelitian dikelompokkan dalam penelitian kausatif. Penelitian kausatif merupakan penelitian yang bertujuan untuk mengetahui hubungan sebab akibat antar variabel melalui pengujian hipotesis.

Data yang digunakan pada penelitian ini merupakan data sekunder. Populasi dalam penelitian ini adalah semua perusahaan LQ 45 yang listing di Bursa Efek Indonesia (BEI) pada periode Februari 2014-Januari 2019.

Untuk pengambilan sampel dilakukan dengan metode purposive sampling yaitu teknik pengumpulan sampel berdasarkan pertimbangan kriteria tertentu. Adapun kriteria yang digunakan antara lain :

1. Perusahaan yang secara konsisten masuk dalam indeks LQ45 di BEI pada periode Februari 2014 - Januari 2019;

2. Perusahaan menyajikan laporan keuangan yang sudah diaudit pada periode $2014-2018$, sehingga tercantum nama KAP yang melakukan audit;

3. Perusahaan tidak melakukan stock split pada periode tahun $2014-2018$.

Berdasarkan kriteria sampel di atas, jumlah sampel yang diperoleh pada penelitian ini adalah sebanyak 25 perusahaan. Jumlah periode pengamatan yang digunakan pada penelitian ini selama 5 tahun. Sehingga jumlah data yang digunakan pada penelitian ini sebanyak 125 data penelitian atau observasi. Pada penelitian ini digunakan variabel independent berupa reputasi KAP, variabel intervening berupa pergantian KAP, dan variabel dependen berupa abnormal return. Tabel 3.1 berikut menjelaskan mengenai pengukuran yang digunakan pada masing-masing variabel: 
Tabel 3.1. Operasionalisasi Variabel

\begin{tabular}{|c|c|c|}
\hline Variabel & Pengukuran & Skala \\
\hline Reputasi KAP & $\begin{array}{l}\text { Menggunakan variabel dumy. Perusahaan yang } \\
\text { menggunakan KAP Big Four mendapat nilai 1, KAP } \\
\text { Non Big Four mendapat nilai } 0\end{array}$ & $\begin{array}{l}\text { Menggunakan } \\
\text { skala nominal }\end{array}$ \\
\hline $\begin{array}{l}\text { Pergantian } \\
\text { KAP secara } \\
\text { voluntary }\end{array}$ & $\begin{array}{l}\text { Menggunakan variabel dummy. Perusahan yang } \\
\text { melakukan pergantian KAP minimal } 1 \text { kali selama } \\
\text { periode penelitian akan mendapat nilai } 1 \text {. Jika tidak } \\
\text { pernah melakukan pergantian KAP mendapat nilai } 0\end{array}$ & $\begin{array}{l}\text { Menggunakan } \\
\text { skala nominal }\end{array}$ \\
\hline $\begin{array}{l}\text { Reaksi } \\
\text { Investor }\end{array}$ & $\begin{array}{l}\text { Pengukuran menggunakan rumus dari abnormal return. } \\
\text { 1. Menghitung return ekspektasi } \\
\qquad \mathrm{E}(\mathrm{Ri}, \mathrm{t})=\mathrm{RMt}=\frac{\mathrm{IHSG}_{\mathrm{t}}-\mathrm{IHSG}_{\mathrm{t}-1}}{\mathrm{IHSG}_{\mathrm{t}-1}} \\
\text { 2. Menghitung Return Sesungguhnya } \\
\qquad \mathrm{Ri}, \mathrm{t}=\frac{\text { Pit }- \text { Pit-1 }}{\text { Pit-1 }} \\
\text { 3. Menghitung Abnormal return } \\
\qquad \mathrm{ARit}=\mathrm{Ri}, \mathrm{t}-\mathrm{RMt}\end{array}$ & $\begin{array}{l}\text { Menggunakan } \\
\text { skala rasio }\end{array}$ \\
\hline
\end{tabular}

Adanya variabel intervening berupa pergantian KAP pada penelitian ini akan membentuk dua persamaan struktural, dimana X1 adalah variabel eksogen dan X2 dan Y adalah variabel endogen. Maka dari itu, persamaan strukturalnya adalah berikut ini:

$$
\begin{aligned}
\mathrm{X} 2 & =\alpha+\mathrm{P}_{1} \mathrm{X} 2 \mathrm{X} 1+\mathrm{e} 1 \ldots \ldots \ldots \ldots \ldots \\
\mathrm{Y} & =\alpha+\mathrm{P}_{2} \mathrm{YX} 1+\mathrm{P}_{3} \mathrm{YX} 2+\mathrm{e} 2 .
\end{aligned}
$$

Keterangan:

$\begin{array}{ll}\mathrm{X} 1 & =\text { Reputasi KAP } \\ \mathrm{X} 2 & =\text { Pergantian KAP } \\ \mathrm{Y} & =\text { Reaksi Investor (abnormal return) } \\ \mathrm{P}_{1} \mathrm{X} 2 \mathrm{X} 1 & =\text { Koefisien jalur Reputasi KAP dengan Pergantian KAP } \\ \mathrm{P}_{2} \mathrm{YX} 1 & =\text { Koefisien jalur Reputasi KAP dengan Reaksi Investor } \\ \mathrm{P}_{3} \mathrm{YX} 1 & =\text { Koefisien jalur Pergantian KAP dengan Reaksi Investor } \\ \alpha & =\text { Konstanta } \\ \mathrm{e} 1 & =\text { Residual atas Kinerja Keuangan } \\ \mathrm{e} 2 & =\text { Residual atas Nilai Perusahaan }\end{array}$

\section{Hasil Penelitian dan Pembahasan}

Statistik Deskriptif. Berdasarkan purposive sampling jumlah sampel yang didapatkan dari hasil pengamatan pada penelitian ini berjumlah 25 perusahaan. Jumlah periode pengamatan yang digunakan pada penelitian ini selama 5 tahun. Sehingga jumlah data yang digunakan pada penelitian ini sebanyak 125 data penelitian.

Analisis statistik deskriptif dalam penelitian ini meliputi mean, minimum, maximum, dan standar deviasi. Pengolahan data untuk analisis deskriptif ini menggunakan program IBM SPSS Statistic 24. Deskripsi data masing-masing variabel secara rinci dapat dilihat dalam tabel berikut: 
Tabel 4.1. Hasil Statistik Deskriptif Descriptive Statistics

\begin{tabular}{lc|c|r|r|r|r} 
& & & & & & \\
& $\mathrm{N}$ & \multicolumn{2}{|c|}{$\begin{array}{c}\text { Minimu } \\
\mathrm{m}\end{array}$} & $\begin{array}{c}\text { Maximu } \\
\mathrm{m}\end{array}$ & \multicolumn{1}{c|}{ Sum } & \multicolumn{1}{c|}{$\begin{array}{c}\text { Mean } \\
\text { Std. } \\
\text { Deviation }\end{array}$} \\
\hline Reputasi KAP & 125 & .00 & 1.00 & 95.00 & .7600 & .42880 \\
\hline Pergantian KAP & 125 & .00 & 1.00 & 20.00 & .1600 & .36808 \\
\hline Abnormal return & 125 & -.55 & 2.95 & 7.83 & .0626 & .52905 \\
\hline Valid N (listwise) & 125 & & & & & \\
\hline
\end{tabular}

Sumber: Data sekunder yang diolah SPSS (2019)

Terdapat N yang merupakan jumlah banyaknya sampel penelitian, yaitu sebanyak 125 sampel perusahaan LQ45 yang terdaftar di Bursa Efek Indonesia (BEI) periode 2014-2018.

\section{Reputasi KAP}

Tabel 4.2. Statistik Frekuensi untuk Reputasi KAP

\section{Reputasi KAP}

\begin{tabular}{lrr|r|r|r} 
& & & & \\
& & Frequency & Percent & Valid Percent & \multicolumn{2}{c}{$\begin{array}{c}\text { Cumulative } \\
\text { Percent }\end{array}$} \\
\hline Valid & .00 & 30 & 24.0 & 24.0 & 24.0 \\
\cline { 2 - 6 } & 1.00 & 95 & 76.0 & 76.0 & 100.0 \\
\hline \multicolumn{1}{l}{ Total } & 125 & 100.0 & 100.0 & \\
\hline
\end{tabular}

Sumber: Data sekunder yang diolah SPSS 24 (2019)

Reputasi KAP merupakan variabel independen yang menggunakan variabel dummy "0" dan " 1 ". Pengukuran reputasi KAP menggunakan dummy dilakukan dengan memberikan nilai "0" bagi perusahaan di LQ45 yang tidak menggunakan jasa audit dari KAP Big Four dan dummy "1" bagi perusahaan di LQ45 yang menggunakan jasa audit dari KAP Big Four.

Hasilnya ditunjukan bahwa dari total keseluruhan 125 sampel perusahaan, hanya terdapat 95 sampel perusahaan yang menggunakan jasa audit KAP Big Four, sedangkan sampel perusahaan yang tidak menggunakan jasa audit KAP Big Four sebanyak 30 perusahaan pada periode 2014-2018. 


\section{Pergantian KAP}

Tabel 4.3. Statistik Frekuensi untuk Pergantian KAP

\begin{tabular}{|c|c|c|c|c|c|}
\hline \multicolumn{6}{|c|}{ Pergantian KAP } \\
\hline & & Frequency & Percent & Valid Percent & $\begin{array}{c}\text { Cumulative } \\
\text { Percent }\end{array}$ \\
\hline \multirow[t]{3}{*}{ Valid } & .00 & 105 & 84.0 & 84.0 & 84.0 \\
\hline & 1.00 & 20 & 16.0 & 16.0 & 100.0 \\
\hline & Total & 125 & 100.0 & 100.0 & \\
\hline
\end{tabular}

Sumber: Data sekunder yang diolah SPSS 24 (2019)

Pergantian KAP merupakan variabel intervening (perantara) yang juga menggunakan variabel dummy " 0 " dan " 1 " dalam pengukurannya. Penggunaan variabel dummy pada variabel pergantian KAP dilakukan dengan memberikan nilai " 0 " untuk sampel perusahaan yang tidak melakukan pergantian KAP dan nilai "1" bagi sampel perusahaan yang melakukan pergantian KAP minimal 1 kali selama periode 2014-2018.

Hasilnya diperoleh data bahwa dari total sampel sebanyak 125 perusahaan, hanya terdapat 20 perusahaan yang melakukan pergantian KAP. Sisanya sebanyak 105 perusahaan tidak pernah melakukan pergantian KAP selama periode 2014-2018.

\section{Reaksi Investor (Abnormal return)}

Reaksi investor menjadi variabel dependen dalam penelitian ini, dan diukur dengan rasio menggunakan rumus abnormal return berdasarkan market adjusted model. Berdasarkan tabel 8, ditunjukkan bahwa nilai minimum dari abnormal return adalah $-0,55$ dan nilai maksimumnya adalah sebesar 2,95.

Sedangkan nilai rata-rata dan standar deviasinya sebesar 0,0626 dan 0,52905. Apabila dilihat dari sampel perusahaan, maka perusahaan dengan nilai abnormal return minimum (terendah) terdapat pada PT Perusahaan Gas Negara (Persero) Tbk di tahun 2017. Sedangkan sampel perusahaan dengan nilai abnormal return maksimum (tertinggi) terdapat pada PT Bank Mandiri (Persero) Tbk di tahun 2014.

Uji Asumsi Klasik. Pada penelitian ini terdapat 2 substruktur regresi dalam bentuk berikut ini:

Persamaan Substruktur 1 :

$$
\mathrm{Y} 1=\mathrm{P} Y \mathbf{Y X} 1+\varepsilon 1
$$

Persamaan Substruktur 2:

$$
\mathrm{Y} 2=\mathrm{P} Y 2 \mathrm{X} 1+\mathrm{P} \mathrm{Y} 2 \mathrm{X} 2+\varepsilon 2
$$




\section{HASIL UJI ASUMSI KLASIK PERSAMAAN SUBSTRUKTUR 1}

\section{a. Uji Normalitas}

Tabel 4.4. Hasil Uji Normalitas Variabel Reputasi KAP

Terhadap Pergantian KAP

One-Sample Kolmogorov-Smirnov Test

\begin{tabular}{lll} 
& & $\begin{array}{l}\text { Unstandardized } \\
\text { Residual }\end{array}$ \\
\hline $\mathrm{N}$ & & 99 \\
\hline Normal Parameters $^{\mathrm{a}, \mathrm{b}}$ & Mean & .0000000 \\
\cline { 2 - 3 } & Std. Deviation & .05330543 \\
\hline Most Extreme Differences & Absolute & .067 \\
\cline { 2 - 3 } & Positive & .067 \\
\cline { 2 - 3 } & Negative & -.065 \\
\hline Test Statistic & & .067 \\
\hline Asymp. Sig. (2-tailed) & & $.200^{\mathrm{c}, \mathrm{d}}$ \\
\hline
\end{tabular}

a. Test distribution is Normal.

b. Calculated from data.

Sumber : Data sekunder yang diolah SPSS 24 (2019)

Hasil uji normalitas dengan menggunakan Kolmogorov-Smirnov dari data Moving Average (MA27) untuk persamaan struktur 1, diperoleh nilai Asymp Sig. (2-tailed) sebesar 0.2 yang lebih besar dari signifikansi sebesar $0,005(0,2>0,05)$. Sehingga dari hasil tersebut dapat disimpulkan bahwa data residual dalam penelitian ini berdistribusi normal.

b. Uji Multikolinearitas

Tabel 4.5. Hasil Uji Multikolinearitas Variabel Reputasi KAP

Terhadap Pergantian KAP

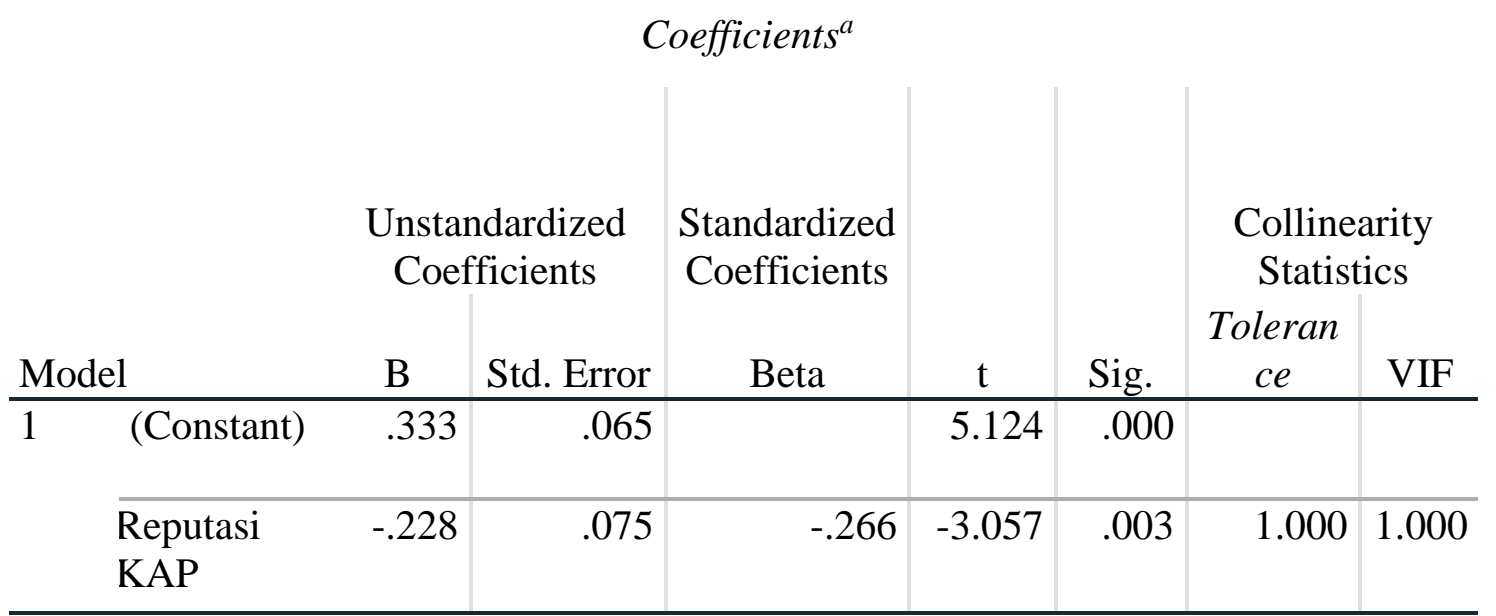

a. Dependent Variable: Pergantian KAP

Sumber : Data sekunder yang diolah SPSS 24 (2019) 
Hasil uji multikolinearitas untuk persaman struktur model 1, ditunjukkan bahwa total nilai Tolerance variabel Reputasi KAP di atas 0,1 yaitu sebesar $1>0,1$. Selanjutnya, hasil perhitungan Variance Inflation Factor (VIF) juga menghasilkan nilai total variabel Reputasi KAP yang berada di bawah 10 yaitu sebesar $1<10$.

\section{c. Uji Autokorelasi}

Tabel 4.6. Hasil Uji Autokorelasi Variabel Reputasi KAP

Terhadap Pergantian KAP

\begin{tabular}{|c|c|c|c|c|c|}
\hline \multirow[b]{2}{*}{ Model } & \multicolumn{4}{|c|}{ Model Sumary ${ }^{b}$} & \multirow[b]{2}{*}{$\begin{array}{l}\text { Durbin- } \\
\text { Watson } \\
\end{array}$} \\
\hline & $\mathrm{R}$ & R Square & $\begin{array}{c}\text { Adjusted R } \\
\text { Square }\end{array}$ & $\begin{array}{l}\text { Std. Error of } \\
\text { the Estimate }\end{array}$ & \\
\hline 1 & $.266^{\mathrm{a}}$ & .071 & .063 & .35629 & 1.687 \\
\hline
\end{tabular}

Sumber : Data sekunder yang diolah SPSS 24 (2019)

Hasil uji autokorelasi untuk persamaan substruktur 1 berdasarkan tabel 13, dapat dilihat bahwa nilai Durbin-Watson sebesar 1,687, yang berada diantara (-2 dan 2). Oleh karena itu, model persamaan substruktur 1 dinyatakan bebas dari autokorelasi.

\section{d. Uji Heteroskedastisitas}

Tabel 4.7. Hasil Uji Heteroskedastisitas Variabel Reputasi KAP

Terhadap Pergantian KAP

Correlations

\begin{tabular}{|c|c|c|c|c|}
\hline & & & $\begin{array}{l}\text { Reputasi } \\
\text { KAP }\end{array}$ & $\begin{array}{c}\text { Unstandardized } \\
\text { Residual }\end{array}$ \\
\hline \multirow[t]{6}{*}{ Spearman's rho } & \multirow[t]{3}{*}{ Reputasi KAP } & $\begin{array}{l}\text { Correlation } \\
\text { Coefficient }\end{array}$ & 1.000 & .038 \\
\hline & & Sig. (2-tailed) & . & .707 \\
\hline & & $\mathrm{N}$ & 99 & 99 \\
\hline & \multirow[t]{3}{*}{$\begin{array}{l}\text { Unstandardize } \\
\text { d Residual }\end{array}$} & $\begin{array}{l}\text { Correlation } \\
\text { Coefficient }\end{array}$ & .038 & 1.000 \\
\hline & & Sig. (2-tailed) & .707 & \\
\hline & & $\mathrm{N}$ & 99 & 99 \\
\hline
\end{tabular}

Sumber: Data yang diolah SPSS 24 (2019)

Hasil uji heteroskedastisitas dengan menggunakan metode rank spearman untuk persamaan substruktur 1, dapat dilihat pada tabel 11. Hasilnya diperoleh nilai Sig. (2-tailed) 
sebesar 0,506 > 0,05 untuk variabel reputasi KAP. Karena nilai Sig. (2-tailed) diatas 0,05 (> 0,05), maka dinyatakan tidak terdapat gejala heteroskedastisitas pada persamaan substruktur 1.

\section{HASIL UJI ASUMSI KLASIK PERSAMAAN SUBSTRUKTUR 2}

\section{a. Uji Normalitas}

Tabel 4.8. Hasil Uji Normalitas Variabel Reputasi KAP dan Pergantian KAP Terhadap Reaksi Investor

One-Sample Kolmogorov-Smirnov Test

\begin{tabular}{llr} 
& & \multicolumn{1}{c}{$\begin{array}{c}\text { Unstandardized } \\
\text { Residual }\end{array}$} \\
\hline $\mathrm{N}$ & Mean & 99 \\
\cline { 2 - 3 } Normal Parameters ${ }^{\mathrm{a}, \mathrm{b}}$ & Std. Deviation & .0000000 \\
\hline Most Extreme Differences & Absolute & .06915710 \\
\cline { 2 - 3 } & Positive & .058 \\
\cline { 2 - 3 } & Negative & .038 \\
\hline Test Statistic & & .058 \\
\hline Asymp. Sig. (2-tailed) & & .058 \\
\hline a. Test distribution is Normal. & & \\
b. Calculated from data. & &
\end{tabular}

Sumber : Data sekunder yang diolah SPSS 24 (2019)

Hasil uji normalitas dengan metode Kolmogorov-Smirnov menggunakan data Moving Average (MA27) untuk persamaan struktur 2, diperoleh nilai Asymp Sig. (2-tailed) sebesar 0.2 yang lebih besar dari signifikansi sebesar $0,005(0,2>0,05)$. Sehingga dari hasil tersebut dapat disimpulkan bahwa data residual dalam penelitian ini berdistribusi normal.

\section{b. Uji Multikolinearitas}

Tabel 4.9. Hasil Uji Multikolinearitas Variabel Reputasi KAP dan Pergantian KAP Terhadap Reaksi Investor

\begin{tabular}{|c|c|c|c|c|c|c|c|}
\hline \multirow[b]{3}{*}{ Model } & \multicolumn{4}{|c|}{ Coefficients $^{\mathbf{a}}$} & \multirow[b]{3}{*}{ Sig. } & \multirow{2}{*}{\multicolumn{2}{|c|}{$\begin{array}{c}\text { Collinearity } \\
\text { Statistics }\end{array}$}} \\
\hline & \multicolumn{2}{|c|}{$\begin{array}{l}\text { Unstandardized } \\
\text { Coefficients }\end{array}$} & \multirow{2}{*}{$\begin{array}{l}\text { Standardize } \\
\mathrm{d} \\
\text { Coefficients } \\
\text { Beta }\end{array}$} & & & & \\
\hline & B & Std. Error & & & & $\begin{array}{c}\text { Toleran } \\
\text { ce }\end{array}$ & VIF \\
\hline $1 \quad$ (Constant) & .100 & .107 & & $\frac{\mathrm{t}}{.934}$ & .352 & & \\
\hline
\end{tabular}




\begin{tabular}{ll|l|l|l|l|l|l}
\hline $\begin{array}{l}\text { Reputasi } \\
\text { KAP }\end{array}$ & -.048 & .116 & -.039 & -.411 & .682 & .929 & 1.076 \\
\hline $\begin{array}{l}\text { Pergantian } \\
\text { KAP }\end{array}$ & -.008 & .135 & -.006 & -.062 & .951 & .929 & 1.076 \\
\hline
\end{tabular}

a. Dependent Variable: Abnormal return

Sumber: Data sekunder yang diolah SPSS 24 (2019)

Hasil uji multikolinearitas untuk persaman struktur model 2, ditunjukkan bahwa total nilai Tolerance variabel Reputasi KAP di atas 0,1 yaitu sebesar 0,929>0,1. Selanjutnya, hasil perhitungan Variance Inflation Factor (VIF) juga menghasilkan nilai total variabel Reputasi KAP yang berada di bawah 10 yaitu sebesar $1.076<10$. Sehingga dari model persamaan substruktur 2 dinyatakan tidak terdapat hubungan diantara kedua variabel bebas.

\section{c. Uji Autokorelasi}

Tabel 4.10. Hasil Uji Autokorelasi Variabel Reputasi KAP dan Pergantian KAP Terhadap Reaksi Investor

\begin{tabular}{|c|c|c|c|c|c|}
\hline \multirow[b]{2}{*}{ Model } & \multicolumn{4}{|c|}{ Model Sumaryb } & \multirow[b]{2}{*}{$\begin{array}{l}\text { Durbin- } \\
\text { Watson }\end{array}$} \\
\hline & $\mathrm{R}$ & $\mathrm{R}$ Square & $\begin{array}{l}\text { Adjusted R } \\
\text { Square }\end{array}$ & $\begin{array}{l}\text { Std. Error of } \\
\text { the Estimate }\end{array}$ & \\
\hline 1 & $.037^{\mathrm{a}}$ & .001 & -.015 & .53300 & 1.800 \\
\hline
\end{tabular}

Sumber: Data yang Diolah SPSS 24 (2019)

Hasil uji autokorelasi untuk persamaan substruktur 2 berdasarkan tabel 17, dapat dilihat bahwa nilai Durbin-Watson sebesar 1.800, yang berada diantara (-2 dan 2). Oleh karena itu, model persamaan substruktur 2 dinyatakan bebas dari autokorelasi.

\section{d. Uji Heteroskedastisitas}

Tabel 4.11. Hasil Uji Heteroskedastisitas Variabel Reputasi KAP dan Pergantian KAP Terhadap Reaksi Investor

\section{Correlations}

\begin{tabular}{|c|c|c|c|c|c|}
\hline & & & $\begin{array}{c}\text { Reputasi } \\
\text { KAP }\end{array}$ & $\begin{array}{l}\text { Pergantian } \\
\text { KAP }\end{array}$ & $\begin{array}{c}\text { Unstandardized } \\
\text { Residual }\end{array}$ \\
\hline \multirow[t]{5}{*}{$\begin{array}{l}\text { Spearman's } \\
\text { rho }\end{array}$} & \multirow[t]{3}{*}{ Reputasi KAP } & $\begin{array}{l}\text { Correlation } \\
\text { Coefficient }\end{array}$ & 1.000 & $.201^{*}$ & -.068 \\
\hline & & Sig. (2-tailed) & & .047 & .506 \\
\hline & & $\mathrm{N}$ & 99 & 99 & 99 \\
\hline & \multirow[t]{2}{*}{$\begin{array}{l}\text { Pergantian } \\
\text { KAP }\end{array}$} & $\begin{array}{l}\text { Correlation } \\
\text { Coefficient }\end{array}$ & $.201^{*}$ & 1.000 & .033 \\
\hline & & Sig. (2-tailed) & .047 & & .746 \\
\hline
\end{tabular}




\begin{tabular}{lll|r|r|r}
\hline & $\mathrm{N}$ & 99 & 99 & 99 \\
\cline { 2 - 6 } $\begin{array}{l}\text { Unstandardized } \\
\text { Residual }\end{array}$ & Correlation & -.068 & .033 & 1.000 \\
& Coefficient & & & \\
\cline { 2 - 6 } & Sig. (2-tailed) & .506 & .746 & 99 \\
\cline { 2 - 6 } & $\mathrm{N}$ & 99 & 99 & \\
\hline
\end{tabular}

Sumber: Data sekunder yang diolah SPSS 24 (2019)

Hasil uji heteroskedastisitas dengan menggunakan metode rank spearman untuk persamaan substruktur 2, dapat dilihat pada tabel 18. Hasilnya diperoleh nilai Sig. (2-tailed) sebesar 0,506 > 0,05 untuk variabel reputasi KAP. Sedangkan variabel pergantian KAP memperoleh nilai Sig. (2-tailed) sebesar 0,746 >0,05. Karena nilai Sig. (2-tailed) masingmasing variabel reputasi KAP dan pergantian KAP diatas $0,05(>0,05)$, maka dinyatakan tidak terdapat gejala heteroskedastisitas pada persamaan substruktur 2 .

\section{Uji Hipotesis}

\section{Analisis Jalur (Path Analysis)}

Analisis jalur merupakan perluasan dari analisis regresi linear berganda. Pada dasarnya koefisien jalur adalah koefisien yang distandarkan (standardized regression weights) atau membandingkan koefisien indirect effect (pengaruh tidak langsung) dengan koefisien direct effect (pengaruh langsung). Selanjutnya akan ditentukan persamaan regresi substruktur 1 dan 2, yaitu:

$\mathrm{X} 2=\alpha+\mathrm{P}_{1} \mathrm{X} 2 \mathrm{X} 1+\mathrm{e} 1$

$\mathrm{Y}=\alpha+\mathrm{P}_{2} \mathrm{YX} 1+\mathrm{P}_{3} \mathrm{YX} 2+\mathrm{e} 2$

Berikut ini adalah hasil persamaan regresi analisis jalur:

\section{Persamaan Substruktur 1}

Tabel 4.12. Analisis Jalur Substruktur 1

\begin{tabular}{|c|c|c|c|c|c|c|}
\hline \multirow{2}{*}{\multicolumn{2}{|c|}{ Model }} & \multicolumn{2}{|c|}{$\begin{array}{l}\text { Unstandardized } \\
\text { Coefficients }\end{array}$} & \multirow[t]{2}{*}{$\begin{array}{c}\text { Standardize } \\
\mathrm{d} \\
\text { Coefficient } \\
\text { s } \\
\text { Beta }\end{array}$} & \multirow[b]{2}{*}{$\mathrm{T}$} & \multirow[b]{2}{*}{ Sig. } \\
\hline & & $\mathrm{B}$ & Std. Error & & & \\
\hline \multirow[t]{2}{*}{1} & (Constant) & .333 & .065 & & 5.124 & .000 \\
\hline & $\begin{array}{l}\text { Reputasi } \\
\text { KAP }\end{array}$ & -.228 & .075 & -.266 & -3.057 & .003 \\
\hline
\end{tabular}

a. Dependent Variable: Pergantian KAP

Sumber: Data yang diolah SPSS 24 (2019)

Hasil output SPSS memberikan nilai standardized coefficients beta Reputasi KAP pada persamaan substruktur 1 sebesar -0,266 yang akan dijadikan sebagai nilai jalur P1 dan 
signifikansi pada $0,003<0,05$. Hal ini berarti reputasi KAP mempengaruhi terjadinya pergantian KAP.

Tabel 4.13. Analisis Koefisien Determinasi Jalur Substruktur 1

\begin{tabular}{rl|r|r|r|r} 
Model & R & R Square & $\begin{array}{c}\text { Adjusted R } \\
\text { Square }\end{array}$ & $\begin{array}{l}\text { Std. Error of } \\
\text { the Estimate }\end{array}$ & $\begin{array}{c}\text { Durbin- } \\
\text { Watson }\end{array}$ \\
\hline 1 & $.266^{\mathrm{a}}$ & .071 & .063 & .35629 & 1.687 \\
\hline
\end{tabular}

a. Predictors: (Constant), Reputasi KAP

b. Dependent Variable: Pergantian KAP

Sumber: Data yang diolah SPSS 24 (2019)

Besarnya nilai R Square yang terdapat pada tabel "Model Sumary" adalah sebesar 0,071, hal ini menunjukkan bahwa sumbangan pengaruh Reputasi KAP (X1) terhadap Pergantian KAP (X2) adalah sebesar 7,1\%. Sementara sisanya sebesar 92.9\% merupakan kontribusi dari variabel-variabel lain yang tidak dimasukkan dalam penelitian.

Selanjutnya, untuk nilai e1 dapat dicari dengan rumus e1 $=\sqrt{(1-0,071)}=0,9638$. Dengan demikian diperoleh rumus persamaan substruktur 1 dan model struktur 1 sebagai berikut:

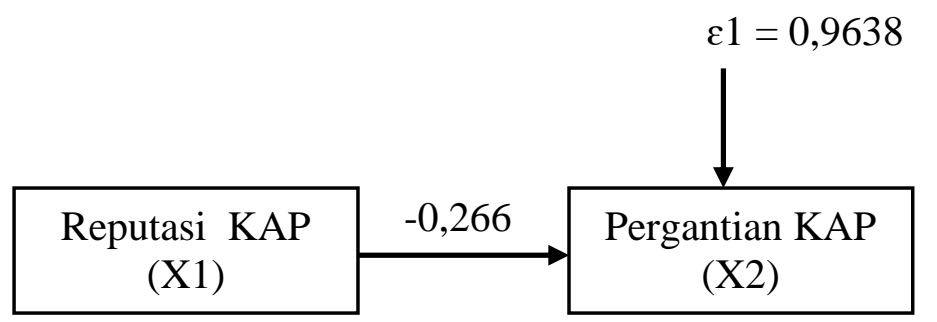

Gambar 2. Model Persamaan Substruktur 1

Persamaan Substruktur 1:

Pergantian KAP $(X 2)=0,333-0,266$ Rep_KAP $+0,9638$

\section{Persamaan Substruktur 2}

Tabel 4.14. Analisis Jalur Substruktur 2

\begin{tabular}{|c|c|c|c|c|c|c|}
\hline \multirow{2}{*}{\multicolumn{2}{|c|}{ Model }} & \multicolumn{2}{|c|}{$\begin{array}{l}\text { Unstandardized } \\
\text { Coefficients }\end{array}$} & \multirow{2}{*}{$\begin{array}{c}\text { Standardized } \\
\text { Coefficients } \\
\text { Beta } \\
\end{array}$} & \multirow[b]{2}{*}{$\mathrm{T}$} & \multirow[b]{2}{*}{ Sig. } \\
\hline & & $\mathrm{B}$ & Std. Error & & & \\
\hline \multirow[t]{3}{*}{1} & (Constant) & .100 & .107 & & .934 & .352 \\
\hline & $\begin{array}{l}\text { Reputasi } \\
\text { KAP }\end{array}$ & -.048 & .116 & -.039 & -.411 & .682 \\
\hline & $\begin{array}{l}\text { Pergantian } \\
\text { KAP }\end{array}$ & -.008 & .135 & -.006 & -.062 & .951 \\
\hline
\end{tabular}

a. Dependent Variable: Abnormal return

Sumber: Data yang diolah SPSS 24 (2019) 
Pada persamaan substruktur 2 nilai standardized coefficients Beta dari reputasi KAP sebesar -0,039 yang akan dijadikan sebagai nilai jalur P2, dengan nilai signifikansi 0,682 > 0,05. Sehingga dinyatakan bahwa reputasi KAP tidak berpengaruh langsung terhadap reaksi investor.

Sedangkan untuk pergantian KAP diperoleh unstandardized sebesar -0,006 yang dijadikan sebagai nilai jalur P3, dengan tingkat signifikansi 0,951 >0,05. Sehingga dinyatakan juga bahwa adanya pergantian KAP tidak berpengaruh langsung terhadap reaksi investor.

Tabel 4.15. Analisis Koefisien Determinasi Jalur Substruktur 2

\begin{tabular}{rr|r|rr|r} 
Model & R & R Square & \multicolumn{1}{|c|}{$\begin{array}{c}\text { Adjusted R } \\
\text { Square }\end{array}$} & $\begin{array}{l}\text { Std. Error of } \\
\text { the Estimate }\end{array}$ & Durbin-Watson \\
\hline 1 & $.037^{\mathrm{a}}$ & .001 & -.015 & .53300 & 1.800 \\
\hline
\end{tabular}

a. Predictors: (Constant), Pergantian KAP, Reputasi KAP

b. Dependent Variable: Abnormal return

Sumber: Data yang diolah SPSS 24 (2019)

Besarnya R Square yang terdapat pada table "Model Sumary" adalah sebesar 0,001 hal ini menunjukkan bahwa kontribusi Reputasi KAP (X1) dan Pergantian KAP (X2) terhadap reaksi investor hanya sebesar $0,1 \%$. Sementara sisanya sebesar $99.9 \%$ merupakan kontribusi dari variabel-variabel lain yang tidak dimasukkan dalam penelitian. Selanjutnya, untuk nilai e2 dapat dicari dengan rumus e $2=\sqrt{(1-0,001)}=0,9995$.

Dengan demikian diperoleh model substruktur 2 dan rumus persamaan substruktur 2 sebagai berikut:

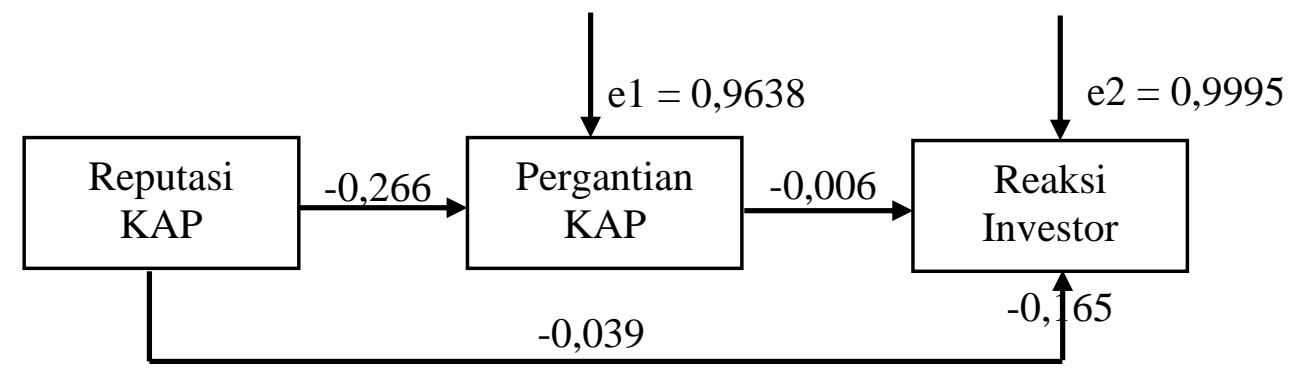

Gambar 3. Model Persamaan Substruktur 2

Persamaan Substruktur 2:

Reaksi Investor $(\mathrm{Y})=0,1-0,039$ Rep_KAP $-0,006$ Perg_KAP + 0,9995

\section{Simpulan dan Saran}

Simpulan. Berdasarkan hasil analisis data mengenai pengaruh reputasi Kantor Akuntan Publik (KAP) terhadap Reaksi Investor dengan Pergantian KAP secara voluntary sebagai variabel intervening pada perusahaan LQ45 yang terdafar di Bursa Efek Indonesia Tahun 2014-2018 dapat ditarik kesimpulan sebagai berikut: 
1. Reputasi Kantor Akuntan Publik tidak memiliki pengaruh langsung terhadap reaksi investor pada perusahan LQ 45 yang terdaftar di BEI tahun 2014-2018. Hal ini ditunjukkan dengan nilai signifikansi sebesar 0,682 > 0,05. Sehingga H0 diterima dan H1 ditolak.

2. Disimpulkan bahwa reputasi KAP berpengaruh terhadap pergantian KAP pada perusahan LQ 45 yang terdaftar di BEI tahun 2014-2018. Hal ini ditunjukan dengan nilai signifikansi sebesar 0,003 $<0,05$. Dengan koefisien determinasi sebesar 7,1\%. Sehingga $\mathrm{H} 2$ diterima dan $\mathrm{H} 0$ ditolak.

3. Pergantian Kantor Akuntan Publik tidak berpengaruh langsung terhadap reaksi investor pada perusahan LQ 45 yang terdaftar di BEI tahun 2014-2018. Hal ini ditunjukkan dengan diperolehnya nilai signifikansi untuk variabel pergantian KAP sebesar 0,951 > 0,05. Sehingga $\mathrm{H} 0$ diterima dan $\mathrm{H} 3$ ditolak.

4. Reputasi Kantor Akuntan Publik berpengaruh terhadap reaksi investor melalui pergantian KAP secara voluntary sebagai variabel intervening (yang menjadi perantara) pada perusahan LQ 45 yang terdaftar di BEI tahun 2014-2018. Hal ini ditunjukkan berdasarkan hasil perhitungan yang sudah dilakukan diperoleh nilai pengaruh langsung dari reputasi KAP terhadap Reaksi investor sebesar $(-0,039)$. Sedangkan besarnya pengaruh tidak langsung dengan adanya pergantian KAP secara voluntary sebagai mediasi antara pengaruh reputasi KAP terhadap reaksi investor sebesar 0,0015. Sehingga H0 ditolak dan H4 di terima.

Saran. Berdasarkan kesimpulan yang sudah dijelaskan sebelumnya, terdapat beberapa saran yang akan disampaikan Penulis, diantaranya adalah:

1. Pada penelitian yang Penulis lakukan hanya digunakan variabel yang berasal dari informasi yang disampaikan perusahaan mengenai keputusan perubahan kebijakan perusahaan, yaitu reputasi KAP dan pergantian KAP. Saran Penulis, untuk penelitian selanjutnya dapat digunakan data yang berhubungan dengan kinerja keuangan, seperti Return On Asset, nilai peusahaan, dan informasi laba.

2. Penelitian selanjutnya dapat menggunakan sektor perusahaan yang berbeda sebagai sampel maupun dngan menambah periode waktu penelitian untuk lebih mendapatkan lebih banyak data yang akan dijadikan sampel penelitian.

3. Penelitian yang akan datang dapat melakukan perhitungan abnormal return dengan metode yang berbeda dari market adjusted model yang Penulis gunakan dalam penelitian ini.

4. Pada penelitian selanjutnya diharapkan menggunakan sampel yang berasal tidak hanya dari Indeks LQ 45, agar dapat memperoleh hasil penelitian yang dapat mewakili semua sektor perusahaan yang tercatat di Bursa Efek Indonesia.

\section{DAFTAR PUSTAKA}

Aprilia, R. \& Effendi, B. (2019). Pengaruh Pergantian Manajemen, Kepemilikan Publik dan Financial Distress terhadap Auditor Switching. STATERA: Jurnal Akuntansi dan Keuangan, 1(1), $61-75$.

Astrini, M. (2013). Analisis Faktor-Faktor Yang Mempengaruhi Perusahaan Melakukan Auditor switching Secara Voluntary. Diponegoro Journal of Accounting, 2(3), 1-11.

Azuar J. \& Irfan, S.M. (2014). Metodologi Penelitian Bisnis, Konsep dan Aplikasi: Sukses Menulis Skripsi \& Tesis Mandiri. Retrieved from https://books.google.co.id/

Cara Melakukan Uji Autokorelasi Dengan Durbin Watson. Retrieved from https://www.statistikian.com/2013/03/durbin-watson-tabel.html 
Cara Uji Analisis Jalur (Path Analysis) dengan SPSS Lengkap. Retrieved from https://www.spssindonesia.com/2017/03/cara-uji-analisis-jalur-path-analysis.html

Anna \& Diputra. (2013). Pengaruh Ketepatan Pelaporan Keuangan, Opini Audit, Pergantian Kantor Akuntan Publik Terhadap Reaksi Investor. Bina Ekonomi Majalah Ilmiah Fakultas Ekonomi Unpar, 18(2), 39-59.

Effendi, Bahtiar. (2018). Pengaruh Ukuran Perusahaan dan Ukuran KAP terhadap Audit Delay. At Negotium Procuratio: Jurnal Bisnis dan Manajemen, 4(1), 21 - 30.

Effendi, Bahtiar. (2018). Profitabilitas, Solvabilitas dan Audit Delay Pada Perusahaan Consumer Goods yang Terdaftar di BEI. OWNER (Riset dan Jurnal Akuntansi), 2(2), $100-108$.

Effendi, Bahtiar. (2019). Kualitas Audit, Kondisi Keuangan, Ukuran Perusahaan dan Penerimaan Opini Audit Going Concern. OWNER (Riset dan Jurnal Akuntansi), 3(1), $9-15$.

Effendi, Bahtiar. (2019). Kondisi Keuangan, Opinion Shopping dan Opini Audit Going Concern pada Perusahaan Pertambangan yang Terdaftar di BEI. STATERA: Jurnal Akuntansi dan Keuangan, 1(1), $34-46$.

Effendi, Bahtiar. (2019). Role Conflict, Role Ambiguity, Independensi dan Kinerja Auditor. STATERA: Jurnal Akuntansi dan Keuangan, 1(2), 155 - 166.

Effendi, Bahtiar. (2019). Komite Audit, Profitabilitas, Solvabilitas, dan Ketepatan Waktu Pelaporan Keuangan Perusahaan Manufaktur-Sektor Logam. Business Innovation and Entrepreneurship Journal, 1(3), 149 - 157.

Effendi, Bahtiar. (2020). Profesional Fee, Pergantian Chief Executive Officer (CEO), Financial Distress dan Real Earnings Management. Jurnal Ilmiah Akuntansi dan Bisnis, 4(2), $105-120$.

Fatkhan Amirul Huda, Pengertian Definisi Operasional. Retrieved from http://fatkhan.web.id/pengertian-definisi-operasional/

Herdiana. (2017). Pengaruh Ketepatan Waktu Pelaporan Laporan Keuangan, Opini Audit, Pergantian Kantor Akuntan Publik, Perubahan Reputasi Kantor Akuntan Publik, dan Informasi Laba Terhadap Reaksi Investor. Jurnal Akuntansi Bisnis, 16(1), 22-38.

Karliana, dkk. (2017). Pengaruh Opini Audit, Reputasi Auditor Dan Audit Fee Terhadap Auditor switching (Studi Pada Perusahaan Sektor Infrasrtuktur, Utilitas, dan Transportasi Yang Terdaftar Di Bursa Efek Indonesia Tahun 2010-2015). EProceeding of Management, 4(2), 1740-1745.

Khasharmeh. (2015). Determinants Of Auditor switching In Bahraini's Listed Companies An Empirical Study. Europan Journal of Accounting, Auditing and Finance Research, 3(11), 73-99.

Ngaijan. (2017). Analisis Pengaruh Pergantian Kantor Akuntan Publik dan Opini Audit Terhadap Reaksi Pasar. Jurnal Saintek Maritim, 16(2), 182-197.

Pengertian dan Cara Menghitung Abnormal return-Event Study. Retrieved from http://www.sahamgain.com/2018/01/pengertian-dan-cara-menghitung-abnormal.html

Priantara. 2017. "Ketika Skandal Fraud Akuntansi Menerpa British Telecom dan PwC. Retrieved from https://www.wartaekonomi.co.id/read145257/ketika-skandal-fraudkuntansi-menerpa-british-telecom-dan-pwc.html

Rochmat Aldy Purnomo. (2014). Analisis Statistik Ekonomi dan Bisnis dengan SPSS. Retrieved from https://books.google.co.id/

Sekarwigati, M. \& Effendi, B. (2019). Pengaruh Ukuran Perusahaan, Profitabilitas, dan Likuiditas terhadap Corporate Social Responsibility Disclosure. STATERA: Jurnal Akuntansi dan Keuangan, 1(1), 16-33. 
Sudarno \& Handoko. (2015). Analisis Pergantian KAP dan Ketepatan Waktu Dalam Pelaporan Terhadap Reaksi Pasar (Studi Empiris Pada Perusahaan Manufaktur yang Terdaftar di BEI). Diponegoro Journal of Accounting, 4(1), 1-14.

Susanto \& Fernandes. (2012). Rekasi Pasar Terhadap Karakteristik Perusahaan dan Kantor Akuntan Publik. Jurnal Bisnis dan Akuntansi, 14(1), 41-53.

Susiani, Yuniarti, \& Restian. (2017). Pengaruh Opini Audit, Reputasi Kantor Akuntan Publik dan Pergantian Manajemen Terhadap Auditor switching Pada Perusahaan Manufaktur yang Terdaftar di BEI Tahun 2010-2015. Profesionalisme Akuntan Menuju Sustainable Business Practice, 620-631.

Susiyanti \& Effendi, B. (2019). Struktur Modal, Ukuran Perusahaan, Likuiditas dan Profitabilitas Perusahaan Manufaktur yang Listing di BEI. OWNER (Riset dan Jurnal Akuntansi), 3(2), $66-72$.

Widnyani, RM. (2018). Pengaruh Opini Audit, Audit Fee, Reputasi KAP dan Ukuran Perusahaan Klien Terhadap Auditor switching. E-Jurnal Akuntansi Universitas Udayana, 23(2), 1119-1145.

Winata, A. (2017). Analysis of Factors Affecting Manufacturing Companies in Indonesia Performing a Switching Auditor. Jurnal Dinamika Akuntansi, 9(1), 82-91. 